\title{
Hakikat Manajemen Dakwah
}

\author{
Adilah Mahmud \\ Institut Agama Islam Negeri Palopo \\ Alamat Surat \\ E-mail: adilah mahmud@email.com
}

\begin{abstract}
Da'wah in the millennial era must now include the virtual dimension and data, by developing a bi-al-oral, bi-al-hall model and hasanah want'idhah together with bi-da'wah and e-da'wah models. Because the challenges in da'wah are very wide, good Da'wah management is needed. The purpose of this study is to describe the rights of preaching management angels. This type of research is a literature study (Library Research). Da'wah management is a series of processes that run continuously in regulating or managing preaching activities to run according to plan and on target. The optimal achievement of the missionary purpose can only be realized by managing the propaganda activity. Da'wah management has 6 functions, i.e. functions as a da'wah planning which includes forecasting or prediction of future conditions and objectives or objectives; see the opportunities and relevance of the da'wah content, establish the procedures for da'wah activities, make da'wah time schedules, determine locations, and prepare funds.
\end{abstract}

Keywords: Management; Da'wah; Bi Al-Verbal; Bi Al-Hall; Bi Al-Kitab

\begin{abstract}
Abstrak
Dakwah di era milenial saat ini harus mencakup dimensi maya dan data, dengan mengembangkan model dakwah bi al-lisan, bi al-hall dan mau'idhah hasanah bersama dakwah bi al-kitab dan e-dakwah. Oleh sebab tantangan dalam berdakwah sangat luas maka diperlukan manajemen dakwah yang baik. Tujuan penelitian ini adalah untuk mendeskripsikan hakaikat manajemen dakwah. Jenis penelitian ini adalah studi pustaka (Library Reseacrh). Manajemen dakwah adalah serangkaian proses yang berjalan secara berkesinambungan dalam mengatur atau mengatur aktivitas dakwah agar berjalan sesuai dengan rencana dan tepat sasaran. Tercapainya tujuan dakwah secara optimal hanya dapat terwujud dengan cara mengatur aktivitas dakwah. Manajemen dakwah memiliki 6 fungsi, yaitu fungsi sebagai perencanaan dakwah yang di dalamnya mencakup forecasting atau prediksi kondisi mad'u di masa mendatang dan objectives atau tujuan; melihat peluang dan relevansi konten dakwah, menetapkan prosedur kegiatan dakwah, membuat time schedule dakwah, menentukan lokasi, dan menyiapkan dana.
\end{abstract}

Kata Kunci,: Manajemen; Dakwah; Bi Al-Lisan; Bi Al-Hall; Bi Al-Kitab 


\section{Pendahuluan}

Berdakwah di era modern ini memiliki banyak peluang dan tantangan, metode pendekatan yang digunakan pun saat ini boleh dikatakan tidak lagi terpaku pada model atau cara berdakwah di masa pra-modern yang hanya mencakup tiga ruang, yaitu dakwah bi al-lisan yang tercermin dengan model dakwah di atas mimbar atau acara-acara tausiyah lainnya; dakwah bi al-hall dengan memberi contoh yang berkehidupan beragama yang baik agar nantinya dicontoh dan diikuti oleh orang lain; dan dakwah dengan mau'idhah hasanah yakni dakwah dengan cara memberi bimbingan, arahan dan nasihat baik yang dimensinya mencakup dakwah bi al-lisan dan bi al-hall.

Dakwah di era digital saat ini dituntut untuk dapat melampaui tiga model dakwah klasik tersebut. Dimensi dakwah kini tidak lagi berkutat pada lisan dan perbuatan sebagai contoh ikutan yang baik, tetapi juga dituntut agar dakwah tersebut tervisualisasi dan terdigitalisasi agar dapat menjangkau berbagai kalangan. Oleh sebab itu perlu adanya dakwah bi al-kitab melalui tulisan-tulisan, $e$-dakwah, dan dakwah melalui lingkungan hidup. ${ }^{1}$

Pelaksanaan dakwah yang dihadang oleh berbagai persoalan yang muncul silih berganti, menjadikan penyelenggara tidak mungkin menghadapinya secara personal yang tidak profesional. Akan tetapi pelaksanaan dakwah harus dilaksanakan secara bersama-sama dalam suatu barisan yang teratur rapi dengan persiapan yang matang serta sistem kerja yang efektif. Dari sinilah perlunya pelaksana dakwah memanfaatkan ilmu manajemen dalam mengelola dakwah.

\section{Metode}

Jenis penelitian yang digunakan dalam penelitian ini adalah studi pustaka (Library Reseacrh). Studi kepustakaan adalah teknik pengumpulan data dengan mengadakan studi penelaahan terhadap buku-buku, literaturliteratur, catatan-catatan, dan laporan-laporan yang ada hubungannya dengan masalah yang ingin dipecahkan. ${ }^{2}$ Penulis melakukan penelusuran terhadap buku-buku, literatur-literatur, artikel, dan sumber lain yang relevan dengan hakikat manajemen dakwah.

Pendekatan kualitatif digunakan untuk mendeskripsikan hakikat manajemen dakwah. Data-data yang dideskripsikan bersumber dari bukubuku dan artikel yang membahas secara khusus maupun buku-buku atau

\footnotetext{
${ }^{1}$ Andy Dermawan, "Manajemen Dakwah Kontemporer di Kawasan Perkampungan: Studi pada Kelompok Pengajian Asmaul Husna, Potorono, Banguntapan, Bantul, DIY," Universitas Islam Negeri Sunan Kalijaga Yogyakarta, Jurnal MD, 2016, h. 2

2 M. Nazir. Metode Peneltian. Jakarta. Ghalia Indonesia. 2003. Hal. 111.
} 
artikel tidak secara spesifik mengenai hakikat manajemen dakwah. Data-data dikumpulkan dengan menggunakan teknik dokumentasi. Penulis mengumpulkan data-data dengan menjadikan buku dan jurnal yang relevan dengan tema sebagai sumber data utama, selain itu juga mengakses berbagai web untuk mencari data-data sebagai tambahan referensi. Analisis data dalam penelitian kualitatif adalah upaya yang dilakukan dengan cara mengorganisasikan data yang berkaitan dengan manajemen dakwah, memilahnya menjadi satuan yang dapat dikelola, menyintesiskannya, mencari dan menemukan hakikat manajemen dakwah, dan memberikan kesimpulan.

\section{Definisi Manajemen Dakwah}

Manajemen dakwah terdiri dari dua kata, yaitu manajemen dan dakwah. Untuk memudahkan pemahaman menyeluruh terhadap manajemen dakwah, maka akan dibahas terlebih dahulu pengertian secara terpisah antara manajemen dengan dakwah, lalu dikemukakan pengertian manajemen dakwah. Istilah manajemen sama tuanya dengan peradaban di Yunani kuno dan Kerajaan Romawi, ${ }^{3}$ pada abad XX istilah ini mulai muncul di negara-negara yang maju dalam suatu cabang ilmu pengetahuan yaitu manajemen. ${ }^{4}$

Manajemen mempunyai kecenderungan mengorganisir dan bekerja bersama-sama dalam hubungan yang saling bergantung merupakan hal yang inherent ${ }^{5}$ oleh orang modern dewasa ini boleh dikatakan tidak ada suatu usaha kerja sama manusia untuk mencapai suatu tujuan tertentu yang tidak mempergunakan manajemen. Dakwah yang mempunyai area yang sangat luas, tidak dapat berjalan secara efisien tanpa diikuti dengan manajemen.

Sepanjang abad 19 dan 20, banyak peneliti yang tertarik pada manajemen yang mengarahkan perhatiannya pada perilaku manusia. Dalam penelitiannya menggunakan peralatan yang baru dan utama terhadap manajemen, seperti pemusatan pada pengambilan keputusan dan analisa sistem-sistem ke dalam arus utama pemikiran manajemen. ${ }^{6}$ Dengan perkembangan tersebut, manajemen dapat berkiprah dan dikembangkan.

${ }^{3}$ G.R. Terry dan L.W. Rue, Principles of Management diterjemahkan oleh G.A. Ticoalu dengan judul Dasar-dasar Manajemen (Cet. VI; Jakarta: Bumi Aksara, 1999), h. 3.

${ }^{4}$ Ilmu Manajemen ini pada awalnya masih diakui sebagai ilmu pengetahuan, pada masa Taylor dan Fayol mulai memajukannya. Lihat J. Panglaykim dan Hazil Tanzil, Manajemen Suatu Pengantar (Cet. XV; Jakarta: Ghalia Indonesia, 1991), h. 15.

${ }^{5}$ Fremont E. Kast dan James E. Rosenzwing, Oganizing and Management. Diterjemahkan oleh A. Hasjmi Ali dengan judul Organisasi dan Manajemen Jilid I (Cet. IV; Jakarta: Bumi Aksara, 1995), h. 3.

${ }^{6}$ Setiap aliran utama pemikiran dalam membantu penelitian manajemen terdapat lima macam pendekatan: Pertama, pendekatan operasional, manajemen dianalisa dari sudut pandang apa yang diperbuat seorang manajer untuk memenuhi persyaratan sebagai seorang manajer. 
Kata manajemen berasal dari bahasa Inggris dari kata kerja to manage yang berarti to direct, to control, to carry on, to cope with, to direct affairs, to seccred. Jadi manajemen berarti the act of managing, administration, body of directors controlling, bussiness. ${ }^{7}$ Apabila dilihat dari asal katanya, maka manajemen dapat berarti memimpin, memberi petunjuk, menyelamatkan atau tindakan memimpin.

Sejak manajemen berdiri sebagai suatu cabang ilmu tersendiri telah banyak definisi yang bermunculan dari para sarjana dan masing-masing berbeda dalam memberikan pengertian, tergantung pada titik tekan dan titik tangkap masing-masing. G.R. Terry dalam merumuskan proses pelaksanaan manajemen mengemukakan bahwa ;

Management is a distinct process consisting of planning, organizing, actuating and controlling, performed to determine and accomplish stated objektives by the use of human beings and other recources. ${ }^{8}$ Artinya Manajemen adalah proses yang khas terdiri dari perencanaan, pengorganisasian, pelaksanaan dan pengawasan yang dilakukan untuk menentukan dan mencapai tujuan yang telah ditetapkan dengan menggunakan tenaga manusia dan sumber daya lainnya.

Robert Kreitener memberikan rumusan manajemen yang menyatakan bahwa: Management is the process of working and trough others to achieve organizational objektives in a changing environment central to this process is the effective and efficient use of limited resources. ${ }^{9}$ Artinya: Manajemen adalah proses bekerja dengan dan melalui orang lain untuk mencapai tujuan organisasi dalam lingkungan yang berubah. Proses ini berpusat pada penggunaan secara efektif dan efisien terhadap sumber daya yang terbatas.

G.R. Terry dan L.W. Rue merumuskan bahwa manajemen adalah suatu proses atau kerangka kerja, yang melibatkan bimbingan atau mengarahkan

Kedua, pendekatan prilaku manusia, hal ini memberi manajemen metode-metode dan konsep-konsep ilmu sosial yang bersangkutan, khususnya psikologi dan antropologi. Ketiga, Pendekatan sistem sosial para pendukung pendekatan ini memandang manajemen sebagai suatu sistem sosial atau sistem interrelasi budaya. Keempat, Pendekatan sistem, konsep sistem umum merupakan bagian-bagian sentral yang dikembangkan pendekatan ini. Kelima, Pendekatan kualitatif titik beratnya adalah penggunaan model-model matematika dan proses hubungan-hubungan dengan data yang dapat dipakai. Lihat G.R. Terry dan L.W. Rue, Principles of Management, h. 32.

7John Gage Allee, Websters Dictionary (Chicago, Wilcox \& Folt Book Company, 1983), h. 228.

${ }^{8}$ George R. Terry, Principle of Management, (6th Edition, Richard D. Irwing Inc. Georgetown , 1972), h. 4.

${ }^{9}$ Robert Kreitner, Management (4th Edition; Boston: Houghton Mifflin Company, 1989), h. 9. 
suatu kelompok orang-orang ke arah tujuan-tujuan organisasional atau maksud-maksud yang nyata. ${ }^{10}$

Dari rumusan manajemen di atas, dapat dipahami bahwa manajemen merupakan suatu proses yang berjalan terus pada suatu arah perbaikan dengan melibatkan orang lain untuk pencapaian tujuan.

Adapun kata dakwah secara etimologi berasal dari bahasa Arab yang merupakan isim masdar dari akar kata دَعْوَةً - يَذْعُوْ - دعا yang maknanya berkisar pada menyeru, mengajak, memanggil dan yang semisalnya. Sedangkan secara terminologi, menurut Yahya Umar dakwah berarti mengajak orang atau manusia ke jalan yang benar dengan cara yang bijaksana sesuai dengan perintah sang Khaliq demi keselamatan dan kebahagiaan fi al-dunya wa alakhirah bagi manusia. ${ }^{11}$

Bila ditinjau pengertian dakwah maka dapat diungkapkan bahwa hakikat dakwah ialah mengajak manusia kepada jalan Allah, pembangunan masyarakat dan amar ma'ruf nahi munkar. Dakwah sebagai ajakan menuju Allah, merupakan hakikat dakwah yang sangat esensial, karena sejalan dengan tugas kearsulan nabi Muhammad saw. yaitu membawa agama tauhid, dapat dipahami dari firman Allah dalam QS. Fushshilat /41: 33.

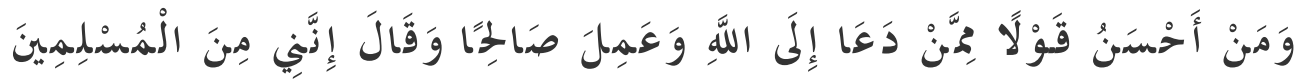

Terjemahnya:

Siapakah yang lebih baik perkataannya daripada orang yang menyeru kepada Allah, mengerjakan amal yang saleh, dan berkata: "Sesungguhnya aku Termasuk orang-orang yang menyerah diri?"12

Dengan demikian dapat dipahami bahwa manajemen dakwah adalah serangkaian proses yang berjalan secara kontinu dalam mengatur aktivitas dakwah agar berjalan sesuai dengan rencana dan tepat sasaran.

\section{Hakikat Manajemen Dakwah}

Jika dikatakan bahwa manajemen selalu diterapkan dalam hubungan dengan usaha orang tertentu dan terkandung adanya suatu tujuan tertentu yang akan dicapai oleh kelompok yang bersangkutan, sedang dakwah selalu diarahkan pada suatu kemajuan yang lebih baik, maka salah satu implikasi pernyataan tersebut ialah bahwa manajemen dakwah puncaknya harus

${ }^{10}$ G.R. Terry dan L.W. Rue, Principle of Management, h. 1.

${ }^{11}$ Sebagaimana dikutip oleh Samsul Munir Amin, Ilmu Dakwah, (Jakarta: Hamzah, 2009), h. 3

${ }^{12}$ Kementerian Agama Republik Indonesia, Alqauran dan Terjemahnya. 
merupakan orang-orang yang mampu memecahkan masalah-masalah atau problem yang dihadapi dakwah.

Terlepas apakah masalah manajemen dakwah itu rumit dan mempunyai dampak kuat untuk jangka panjang atau relatif sederhana dan dengan dampak yang tidak kuat dan hanya bersifat jangka pendek atau sedang. Yang jelas ialah bahwa pendekatan dan teknik yang digunakan harus mampu mencabut akar permasalahan dan tidak sekedar mengobati gejalagejalanya saja.

Menurut Amrullah Ahmad bahwa pada hakikatnya dakwah Islam merupakan aktualisasi iman yang dimanifestasikan dalam suatu sistem kegiatan manusia beriman yang termaktub dalam berbagai bidang kehidupan masyarakat. ${ }^{13}$

Manajemen dakwah merupakan suatu proses yang dinamik karena ia berlangsung secara terus menerus dalam suatu organisasi. Setiap perencanaan selalu memerlukan peninjauan ulang dan bahkan mungkin perubahan di masa depan. Pertimbangannya adalah kondisi yang dihadapi selalu berubah-ubah. Manajemen dakwah dimaksudkan agar pelaksana dakwah mampu menampilkan kinerja tinggi. Hanya dengan demikianlah hakikat pencapaian tujuan dan berbagai sasarannya dapat dicapai dengan baik. Adapun fungsi manajemen dakwah adalah sebagai berikut:

\section{Fungsi Perencanaan Dakwah}

Pada perencanaan dakwah terkandung di dalamnya mengenai hal-hal yang harus dikerjakan seperti apa yang harus dilakukan, kapan, di mana dan bagaimana melakukannya? Dalam Kamus Besar Bahasa Indonesia disebutkan bahwa perencanaan dapat berarti proses, perbuatan, cara mencanankan atau merancangkan. ${ }^{14}$

Perencanaan dapat berarti menentukan tujuan-tujuan yang hendak dicapai selama suatu masa yang akan datang dan apa yang harus diperbuat agar dapat mencapai tujuan-tujuan itu. ${ }^{15}$ Dengan demikian, perencanaan merupakan proses pemikiran, baik secara garis besar maupun secara detail dari satu pekerjaan yang dilakukan untuk mencapai kepastian yang paling baik dan ekonomis.

Perencanaan merupakan gambaran dari suatu kegiatan yang akan datang dalam waktu tertentu dan metode yang akan dipakai. Oleh karena

\footnotetext{
${ }^{13}$ Amrullah Ahmad (ed.), Sebagaimana dikutip Didin Hafiduddin, h. 177.

${ }^{14}$ Tim Penyusun Kamus Pusat Pembinaan dan Pengembangan Bahasa, Kamus Besar Bahasa Indonesia (Cet. III; Jakarta: Balai Pustaka, 1990), h. 741.

${ }^{15}$ G.R. Terry dan L.W. Rue , h. 9. Simak pula J. Panglaykim dan Hazil Tanzil, Manajemen Suatu Pengantar, h. 39. Lihat pula Soekarno K, Dasar-dasar Manajemen (Cet. XIV; Jakarta: Miswar, 1986), h. 71.
} 
itu, perencanaan merupakan sikap mental yang diproses dalam pikiran sebelum diperbuat, ia merupakan perencanaan yang berisikan imajinasi ke depan sebagai suatu tekad bulat yang didasari nilai-nilai kebenaran. Oleh karena itu, kegiatan-kegiatan dakwah dapat diatur sedemikian rupa, sehingga dapat mencapai sasaran dan tujuannya. ${ }^{16}$

Berdasarkan uraian di atas, maka proses perencanaan dakwah meliputi langkah-langkah sebagai berikut ;

a) Forecasting

Forecasting adalah usaha untuk meramalkan kondisi-kondisi yang mungkin terjadi di masa datang. ${ }^{17}$ Perencanaan dakwah di masa datang memerlukan perkiraan dan perhitungan yang cermat sebab masa datang adalah suatu prakondisi yang belum dikenal dan penuh ketidakpastian yang selalu berubah-ubah.

Dalam memikirkan perencanaan dakwah masa datang, jangan hanya hendaknya mengisi daftar keinginan belaka. Di dalam al-Qur'an telah diterangkan perlunya forecasting, sebagaimana disebutkan dalam QS. al-Hasyr/59: 18

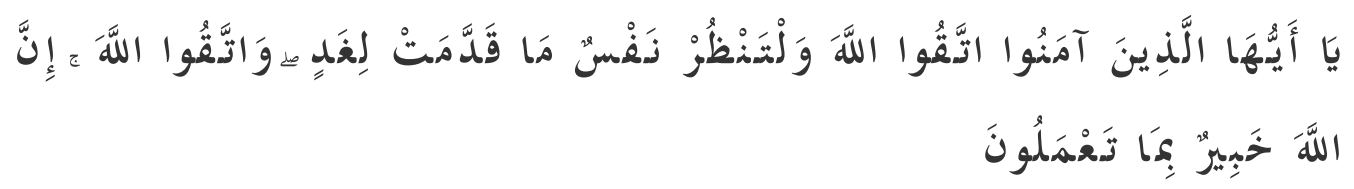

Terjemahnya:

Hai orang-orang yang beriman, bertakwalah kepada Allah dan hendaklah Setiap diri memperhatikan apa yang telah diperbuatnya untuk hari esok

\footnotetext{
16 Tujuan dakwah Islam dirinci ke dalam beberapa tujuan, yaitu: 1. Pembebasan dari berbagai perbudakan, terdiri atas; a. Pembebasan dari perbudakan QS. (2) : 177; (9) : 60 (4) : 92; (5) : 89; (58) : 3. b. Pembebasan dari kemiskinan, c. pembebasan manusia dari kebekuan. 2. Mencapai keseimbangan antara material dan spiritual QS. (49) : 7-8; (7) : 31; (28) : 77. 3. Jihad fi sabilillah QS. (16) : 125; (22) : 39-40. 4. Pembentukan umat yang bersatu padu. Lihat selengkapnya Muhamamd Mustafa Atha, Da'watu Tahririyati al-Kubra dialih bahasakan oleh H.M. Asywadie Syukur dengan judul Sejarah Dakwah Islam (Cet. I; Surabaya: 1982), h. 105-143. Sedangkan Didin Hafiduddin melihat lebih jauh lagi tujuan akhir dari dakwah ialah ridha dan magfirah Allah swt. namun untuk mencapai tujuan tersebut perlu diwujudkan terlebih dahulu sasaran yang bersifat duniawi. Lihat Abu Ridha, Problematika Dakwah (Problema visi dan implikasinya) dalam Adi Sasono at. all, h. 215.

${ }^{17}$ Lihat G.R. Terry, dan L. W. Rue, Principles of Management diterjemahkan oleh G.A. Ticoalu dengan judul Dasar-dasar Manajemen, h. 56.
} 
(akhirat); dan bertakwalah kepada Allah, Sesungguhnya Allah Maha mengetahui apa yang kamu kerjakan. ${ }^{18}$

Dengan demikian, jelaslah bahwa dalam rangka forecasting diperlukan adanya kemampuan untuk lebih jelih di dalam memperhitungkan dan memperkirakan kondisi objektif kegiatan dakwah di masa datang, terutama lingkungan yang mengitari kegiatan dakwah, seperti keadaan sosial, politik, ekonomi dan kebudayaan yang mempunyai pengaruh (baik langsung maupun tidak langsung) pada setiap pelaksanaan dakwah.

Dalam kerangka forecasting ini, berbagai tindakan yang perlu diperhatikan adalah:

1) Evaluasi keadaan

Hal ini dilakukan untuk melihat pelaksanaan rencana dakwah yang lalu terwujud. Dari hasil telaah dan penelitian itu, maka dapat diketahui keberhasilan dan kegagalan pelaksanaannya. Dari situ dapat diketahui penyimpangan-penyimpangan yang terjadi, sehingga memerlukan tindak lanjut perbaikan di masa datang.

2) Membuat Perkiraan-perkiraan

Langkah ini dilakukan berdasarkan kecenderungan masa lalu, dengan bertolak pada asumsi; kecenderungan masa lalu diproyeksikan pada masa yang akan datang, peristiwa yang terjadi berulang-ulang pada masa datang, menghubungkan suatu peristiwa dengan peristiwa yang lain.

\section{b) Objectives}

Objectives diartikan sebagai tujuan. Sedangkan yang dimaksud dengan tujuan adalah nilai-nilai yang akan dicapai atau diinginkan oleh seseorang atau badan usaha. Untuk mencapai nilai-nilai itu dia bersedia memberikan pengorbanan atau usaha yang wajar agar nilai-nilai itu terjangkau. ${ }^{19}$

Penyelenggaraan dakwah dalam rangka pencapaian tujuan, dirangkai ke dalam beberapa kegiatan melalui tahapan-tahapan dalam periode tertentu.

Penetapan tujuan ini merupakan langkah kedua sesudah forecasting. Hal ini menjadi penting, sebab gerak langkah suatu kegiatan akan diarahkan kepada tujuan. Oleh karena itu, ia merupakan suatu keadaan yang tidak boleh tidak harus menjadi acuan pada setiap pelaksanaan dakwah.

\footnotetext{
${ }^{18}$ Kementerian Agama Republik Indonesia, Alquran dan Terjemahnya.

19Davis R.C., The Fundamental of Top Management (t.t.: Harpes Bros, 1951), h. 90.
} 
Tujuan tersebut harus diarahkan pada sasaran dakwah yang telah dirumuskan secara pasti dan menjadi arah bagi segenap tindakan yang dilakukan pimpinan. Tujuan tersebut diwujudkan dalam bentuk target atau sasaran kongkret yang diharapkan dapat dicapai. ${ }^{20}$

2. Mencari Berbagai Tindakan Dakwah

Tindakan dakwah harus relevan dengan sasaran dan tujuan dakwah, mencari dan menyelidiki berbagai kemungkinan rangkaian tindakan yang dapat diambil, sebagai tindakan yang bijaksana.

Tindakan dakwah harus sinkron dengan masyarakat Islam, sehingga tercapai sasaran yang telah ditetapkan. Ketidaksinkronan dalam menentukan isi dakwah dapat menimbulkan dampak negatif terhadap pribadi muslim.

Oleh karena itu, jika sudah ditemukan berbagai alternatif tindakan, maka perencana harus menyelidiki berbagai kemungkinan yang dapat ditempuh, dalam arti bahwa perencana harus memberikan penilaian terhadap kemungkinan tersebut.

Pada tiap-tiap kemungkinan tersebut, harus diperhitungkan untung ruginya dengan mempertimbangkan faktor-faktor yang mempengaruhinya. Hal ini menjadi dasar pengambilan keputusan.

3. Prosedur kegiatan

Prosedur adalah serentetan langkah-langkah akan tugas yang berkaitan, ia menentukan dengan cara-cara selangkah demi selangkah metode-metode yang tepat dalam mengambil kebijakan. ${ }^{21}$

Prosedur kegiatan tersebut merupakan suatu gambaran mengenai sifat dan metode dalam melaksanakan suatu pekerjaan, atau dengan kata lain, prosedur terkait dengan bagaimana melaksanakan suatu pekerjaan.

4. Penjadwalan (Schedul)

Schedule merupakan pembagian program (alternatif pilihan) menurut deretan waktu tertentu, yang menunjukkan sesuatu kegiatan harus diselesaikan. Penentuan waktu ini mempunyai arti penting ${ }^{22}$ bagi proses dakwah.

20Zaini Muchtarom, Dasar-Dasar Manajemen Dakwah (Cet. I; Yogyakarta: al-Amin Press, 1996), h. 41-42.

${ }^{21}$ G.R. Terry dan L.W. Rue, Principles of Management, h. 69.

${ }^{22}$ Karena mengulur-ulur waktu, pada hakekatnya membuang waktu yang sangat berharga. Lihat SP. Siagian, Eksekutifyang Efektif (Cet. I; Jakarta: Gunung Agung, 1996), h. 11. 
Dengan demikian, waktu dapat memicu motivasi. ${ }^{23}$ Untuk itu perlu diingat bahwa batas waktu yang telah ditentukan harus dapat ditepati, sebab menurut Drucker semakin banyak menghemat waktu untuk mengerjakan pekerjaan merupakan pekerjaan profesional. ${ }^{24}$

\section{Penentuan Lokasi}

Penentuan lokasi yang tepat, turut mempengaruhi kualitas tindakan dakwah. Oleh karena itu, lokasi harus dilihat dari segi fungsionalnya dari segi untung ruginya, sebab lokasi sangat terkait dengan pembiayaan, waktu, tenaga, fasilitas atau perlengkapan yang diperlukan. Untuk itulah lokasi merupakan bagian yang tidak terpisahkan dalam rangka perencanaan dakwah.

6. Dana

Setiap kegiatan memerlukan dana, kegiatan tanpa ditunjang oleh dana yang memadai, akan turut mempengaruhi pelaksanaan dakwah. Pusat Dakwah Islam Indonesia memberikan definisi tentang dana dakwah, yaitu segala tenaga atau modal uang peralatan yang dapat dipergunakan dalam kegiatan dakwah. ${ }^{25}$ Batasan tersebut meliputi segala perbendaharaan yang bernilai material yang dapat dimanfaatkan sebagai sarana dalam pelaksanaan dakwah.

Perintah berkorban dengan harta didahulukan dari pada berkorban dengan jiwa, karena dana sangat dibutuhkan baik di waktu damai maupun di waktu perang. ${ }^{26}$ Pernyataan tersebut sesuai dengan firman Allah dalam QS. al-Taubah /9: 41.

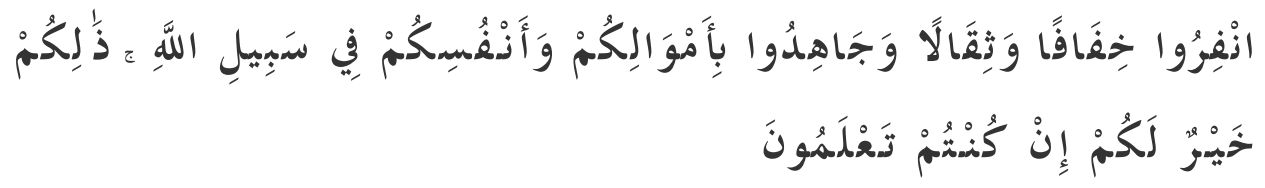

Terjemahnya:

Berangkatlah kamu baik dalam Keadaan merasa ringan maupun berat, dan berjihadlah kamu dengan harta dan dirimu di jalan Allah. yang demikian itu adalah lebih baik bagimu, jika kamu mengetahui. ${ }^{27}$

\footnotetext{
${ }^{23}$ Harold L. Taylor, Time Management diterjemahkan oleh Dadan Riskomar dengan judul Manajemen Waktu: Suatu Pedoman Pengelolaan Waktu dan Produktif (Cet. I; Jakarta: Bina Aksara, 1990), h. 10.

${ }^{24}$ Peter F. Drucker, Bagaimana Menjadi Eksekutif yang Efektif (Cet. I; Jakarta: Pedoman Ilmu Jaya, 1986), h. 41.

25Pusat Dakwah Islam Indonesia, Forum Dakwah (Jakarta: t.p., 1971), h. 306.

26Pusat Dakwah Islam Indonesia, Forum Dakwah, h. 306.

${ }^{27}$ Kementerian Agama Republik Indonesia, Alquran dan Terjemahnya.
} 
Ayat tersebut menyertakan harta sebagai sarana berjihad di jalan Allah, memang benar saat ini dakwah tanpa ditunjang dengan finansial yang memadai tidak akan berjalan secara optimal. Oleh sebab itu 6 fungsi manajemen dakwah tersebut merupakan petunjuk dasar dalam menjalankan aktivitas dakwah agar dakwah dapat terlaksana dan mencapai sasaran seperti yang diharapkan.

\section{Kesimpulan}

Manajemen dakwah terdiri dari dua kata, yaitu manajemen dan dakwah. Kata managemen berasal dari bahasa Inggris dari kata kerja to manage yang berarti to direct, to control, to carry on, to cope with, to direct affairs, to seccred. Jadi manajemen berarti the act of managing, administration, body of directors controlling, bussiness. Sedangkan dakwah yang secara etimologi berasal dari bahasa Arab yang merupakan isim masdar dari akar kata دَعْوَةً - يَذْعُوْ - دعا yang maknanya berkisar pada menyeru, mengajak, dan memanggil. Manajemen dakwah adalah serangkaian proses yang berjalan secara kontinu dalam mengatur aktivitas dakwah agar berjalan sesuai dengan rencana dan tepat sasaran. Tercapainya tujuan dakwah secara optimal hanya dapat terwujud dengan cara mengatur aktivitas dakwah. Manajemen dakwah memiliki 6 fungsi, yaitu fungsi sebagai perencanaan dakwah yang di dalamnya mencakup forecasting atau prediksi kondisi mad'u di masa mendatang dan objectives atau tujuan; melihat peluang dan relevansi konten dakwah, menetapkan prosedur kegiatan dakwah, membuat time schedule dakwah, menentukan lokasi, dan menyiapkan dana.

\section{Daftar Pustaka}

Kementerian Agama Republik Indonesia, Alqauran dan Terjemahnya.

Allee, John Gage. Websters Dictionary (Chicago, Wilcox \& Folt Book Company, 1983).

Amin, Samsul Munir. Ilmu Dakwah, (Jakarta: Hamzah, 2009)

Atha, Muhamamd Mustafa. Da'watu Tahririyati al-Kubra dialih bahasakan oleh H.M. Asywadie Syukur dengan judul Sejarah Dakwah Islam (Cet. I; Surabaya: 1982)

Davis R.C., The Fundamental of Top Management (t.t.: Harpes Bros, 1951)

Dermawan, Andy. "Manajemen Dakwah Kontemporer di Kawasan Perkampungan: Studi pada Kelompok Pengajian Asmaul Husna, Potorono, Banguntapan, Bantul, DIY," Universitas Islam Negeri Sunan Kalijaga Yogyakarta, Jurnal MD, 2016. 
Drucker, Peter F. Bagaimana Menjadi Eksekutif yang Efektif (Cet. I; Jakarta: Pedoman Ilmu Jaya, 1986)

J. Panglaykim dan Hazil Tanzil, Manajemen Suatu Pengantar (Cet. XV; Jakarta: Ghalia Indonesia, 1991)

Kast. Fremont E. dan James E. Rosenzwing, Oganizing and Management. Diterjemahkan oleh A. Hasjmi Ali dengan judul Organisasi dan Manajemen Jilid I (Cet. IV; Jakarta: Bumi Aksara, 1995)

Kreitner, Robert. Management (4th Edition; Boston: Houghton Mifflin Company, 1989)

Muchtarom, Zaini. Dasar-Dasar Manajemen Dakwah (Cet. I; Yogyakarta: alAmin Press, 1996).

Soekarno K, Dasar-dasar Manajemen (Cet. XIV; Jakarta: Miswar, 1986)

SP. Siagian, Eksekutifyang Efektif (Cet. I; Jakarta: Gunung Agung, 1996)

Taylor, Harold L. Time Management diterjemahkan oleh Dadan Riskomar dengan judul Manajemen Waktu: Suatu Pedoman Pengelolaan Waktu dan Produktif (Cet. I; Jakarta: Bina Aksara, 1990)/

Terry, G.R. dan L.W. Rue, Principles of Management diterjemahkan oleh G.A. Ticoalu dengan judul Dasar-dasar Manajemen (Cet. VI; Jakarta: Bumi Aksara, 1999).

Terry, George R. Principle of Management, (6th Edition, Richard D. Irwing Inc. Georgetown, 1972)

Tim Penyusun Kamus Pusat Pembinaan dan Pengembangan Bahasa, Kamus Besar Bahasa Indonesia (Cet. III; Jakarta: Balai Pustaka, 1990) 